
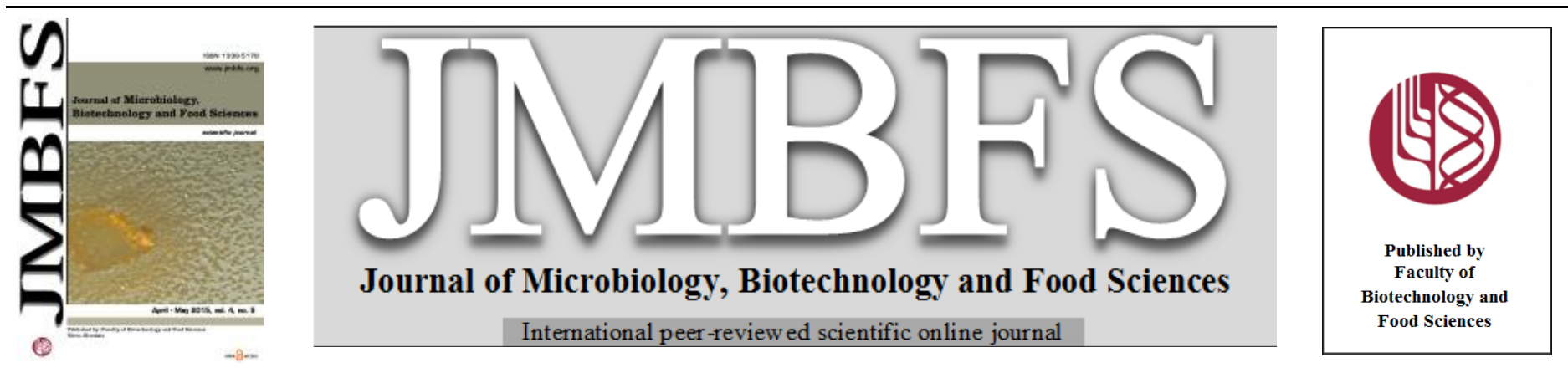

\title{
DETERMINATION OF LEAD (Pb), IRON (Fe) AND MANGANESE (Mn) CONCENTRATION IN SEWAGE WATER AND VEGETABLE LEAF SAMPLES
}

\author{
Muhammad Umar Hayat ${ }^{1}$, Abdul Waqas ${ }^{1}$, Shafaqat Ali ${ }^{1 *}$, Mujahid Farid $^{1}$, Rehan Ahmad ${ }^{1}$, Hafiz Muhammad Tauqeer ${ }^{2}$, Usman \\ Iftikhar $^{I}$, Faakhir Hannan ${ }^{1}$
}

\author{
$\operatorname{Address(es):~}$ \\ ${ }^{1}$ Department of Environmental Sciences and Engineering, Government College University, Allama Iqbal Road, 38000, Faisalabad, Pakistan. \\ ${ }^{2}$ Department of Environmnetal Sciences, University of Gujrat, Gujrat, Pakistan.
}

*Corresponding author: shafaqataligill@yahoo.com

doi: 10.15414/jmbfs.2015.4.5.387-392

\section{ARTICLE INFO}

Received 15. 10. 2014

Revised 8. 1. 2015

Accepted 16. 1.2015

Published 1. 4. 2015

Regular article

OPEN $\partial_{\text {ACCESS }}$

\begin{abstract}
Application of waste water for irrigation purposes has increased over the past years. This waste water contains high amounts of trace elements and heavy metals.Many of these are non-essential and toxic to plants, animals and human beings. The use of polluted water in the immediate surroundings of big cities in Pakistan is a common practice for growing of vegetables. When this water applied for long time in irrigation, these heavy metals may accumulate in soil and that may be toxic to plants and also cause deterioration of soil. The present study revealed that heavy metal content was above the toxicity level in leafy vegetables grown in the area of Lahore. This study showed that among the different tested plant species, the amount of heavy metals was more in leaves than fruits. Plants whose fruits grow below the soil showed higher concentration of heavy metals while other showed less concentration whose edible portion was above the ground level. Leafy vegetables (spinach, cabbage, coriander etc) showed higher concentration in leaves than in fruits. The concentration of heavy metals in upper layer of soil $(0-15 \mathrm{~cm})$ is higher than the lower layer $(15-30 \mathrm{~cm})$. The reason behind is that the upper layer was receiving sewage water permanently while the penetration of sewage water below $15 \mathrm{~cm}$ was less. The increase in heavy metal accumulation in different plant species and their different parts is not constant and is not in proportion to the increase in heavy metal concentration in soil irrigated with sewage wastewater.
\end{abstract}

Keywords: Accumulate, growth, heavy metal, spinach, vegetable

\section{INTRODUCTION}

Water is an essential molecule needed by all living things for their survival and existence on this planet. About $(6 \%)$ water is used for domestic, $(3 \%)$ for industrial and $(90 \%)$ of available water is used for irrigation purposes (Tarar, 1997). The use of urban waste water (sewage and industrial effluents) for growing vegetables especially in areas around cities is the common practice now a days (Lone, 1995). Use of waste water for irrigation gives very good crop yields because it contains large amount of organic material and inorganic elements essential for proper growth and development of crops (Mitra and Gupta, 1999; Siddique et al., 2014).

Two of the main sources of heavy metal pollution are geological and anthropogenic activities (Dembitsky, 2003; Farid et al., 2013a). Anthropogenic sources of heavy metal contamination come from industrial effluents, mining, fuel production, military operations, smelting processes, utilization of agricultural chemicals, brick kilns, small-scale industries and coal combustion (Zhen-Guo et al., 2002). One of the dominant sources taking part in increased budget of soil pollution include municipal waste disposal, this may be roadside dumping or end up in landfills, while sewage consumed for irrigation purposes. These contaminants are although a handy source of nutrients, but are proved to be carcinogens and sources of toxic metals.

Irrigation with wastewater is known to contribute significantly to the heavy metals content of soil. Industrial activities such as mining, electroplating and manufacturing of essential commodities produce huge volume of waste water as effluents containing heavy metals and other toxicants, which deteriorate the quality of aquatic system (Abbas et al., 2007; Ehsan et al., 2013)

Sewage water contains significant amounts of heavy metals such as zinc ( $\mathrm{Zn})$, manganese $(\mathrm{Mn})$, lead $(\mathrm{Pb})$, cadmium $(\mathrm{Cd})$ and chromium $(\mathrm{Cr})$. Some of the heavy metals are toxic for plants and after accumulating in the soil they transferred to food chain (Malla et al., 2007).

It has been observed that the food crops grown on contaminated soils take up metals excessively. The abundant amounts of beneficial nutrients with toxic heavy metals are found in the waste water which is creating both the problems and opportunities for agricultural production (Chen et al., 2005; Ehsan et al., 2013).

Heavy metals toxicity is the result of complex interaction of major toxic ions with other essential or non-essential ions. Heavy metals reduce the activity of hydrolysis viz., an amylase, phosphatase, RNAse and proteins. They interfere in the enzyme action by replacing metal ions from the metal enzymes. Among heavy metals cadmium shows severe effect on seedling length, dry weight, reduces photosystem II activity, causes structural changes in chloroplast and thus reduces photosynthesis, availability of carbon dioxide, lowers stomata conductance, reduces total lipids, glycolipids and neutral lipids, interfere with membrane permeability and reduces respiration in leaves (Agarwal, 2002; Farid et al., 2013b).

So the present study was conducted to assess the concentration of metals in sewage water, different strata of soils and different parts of plants in the selected areas of Lahore.

\section{MATERIAL AND METHODS}

The present experiment was conducted for the analysis of lead, iron and manganese in plants and soil samples irrigated with sewage water permanently in the Institute of soil chemistry and environmental sciences, AARI, Faisalabad.

\section{Collection of Samples}

The selected fields were located adjacent to the Taj Company drain, Band road drain (double sarak wala nala), Bakar Mandi drain, Ravi Sewage water areas were (1). Shadra River Area, (2). Ravi River Area, (3). Chota Sandha Kalan, (4). Akram Park, (5). Darogha Wala, (6). Ghosia Colony and (7). Faryad Colony near T-5 Ravi River in Lahore city, Punjab, Pakistan. All these sites were cultivitaed with different vegitables/ fruits. Total 25 samples were collected from these sites randomly covering all vegitables/ fruits types. Samples of soil and plants (leaves and fruits) were collected from these sites. 


\section{Sewage water analysis}

\section{Method}

Samples of sewage water were collected randomly from different collection sites. The $\mathrm{pH}$ and EC of samples was determined by $\mathrm{pH}$ meter and EC meter. Then filter the samples with Whatman 42 filter paper and store the samples in storage bottles. Read the $\mathrm{Pb}$ concentration by Atomic Absorption spectrophotometer (AAS) (Vanselow and Liebig, 1948).

\section{Calculation}

$\mathrm{c}_{1} \mathrm{~V}_{1}=\mathrm{c}_{2} \mathrm{~V}_{2}$

$\mathrm{c}_{1}=$ concentration of stock solution

$\mathrm{V}_{1=\text { volume to be determined }}$

$\mathrm{c}_{2=}$ concentration to be made

$\mathrm{V}_{2=}$ known volume

\section{Soil sampling method}

After considering average field conditions i.e. extreme high and low value, for example, slope, appearance of crop and a grid line was established at regular intervals $(15-30 \mathrm{~m})$ and each intersection $1 \mathrm{~m}$ diameter area was sampled by taking 8-10 course. The depth of sampling was chosen according to land use. For shallow rooted crops $(0-6 \mathrm{~cm})$ and for long rooted crops $6-12 \mathrm{~cm}$ was suitable.

\section{Soil analysis}

\section{Method for Soil Analysis}

$25 \mathrm{~g}$ soil sample was taken and $50 \mathrm{ml}$ of DTPA solution added to it. Then it was shaken continuously for 2 hours on horizontal shaker and was filtered. A blank solution (containing all reagents except soil) was run with samples as blank. Read each element concentration on concentration mode by Atomic Absorption Spectrophotometer (Vanselow and Liebig, 1948).

\section{Calculations required}

Heavy Metal $(\mathrm{ppm})=$ AAS reading $\mathrm{x}$ dilution factor

\section{Plant sampling and analysis}

Sampling was carried out from vegetable farms located along drain where vegetables were grown by untreated sewage water.

ForPlant sampling, leaves and fruits (edible portion) were taken randomly from different vegetable crops. Plant samples were washed and cut into pieces, air dried in Fluidized Bed Dryer at $80^{\circ} \mathrm{C}$ for $4 \mathrm{hrs}$. The dried material was then powdered in a hammer mill. The samples of plants were homogenized before air drying and stored in clean, sample bottles which were used in plant analysis according to requirements.

\section{Dry ashing for Plant analysis}

Method

$1 \mathrm{~g}$ of dried and grinded sample of plant (leaves and fruit) was weighed in crucibles and then the crucibles were placed in furnace for $2-3$ hours at $550{ }^{\circ} \mathrm{C}$ After letting the crucibles to cool down they were taken out from the furnace. Then $5 \mathrm{ml}$ of $2 \mathrm{M} \mathrm{HCl}$ was added to each crucible to dissolve the ash. The crucibles were placed on hot plate at low temperature to dissolve ash completely. If ash remained un-dissolve add more $\mathrm{HCl}$ and heat on hot plate until complete mixing. Then these plant samples were diluted up to $50 \mathrm{ml}$ with distilled water After dilution each solution was filtered using Watman-42 filter paper and stored in sampling bottles.

A blank solution (containing all reagents except plant sample) was also digested with samples as blank. Read on concentration mode by Atomic Absorption spectrophotometer (Vanselow and Liebig, 1948).

\section{Calculations required}

Heavy metal $(\mathrm{ppm})=$ AAS reading $\mathrm{x}$ dilution factor

\section{Statistical analysis}

All values showed in this paper are mean of three replicates. Analysis of variance (ANOVA) was carried by using a statistical package, SPSS version16.0 (SPSS, Chicago, IL) followed by Tukey test between the means of treatments to determine the significant difference

\section{RESULTS AND DISCUSSION}

\section{pH of Sewage Water}

The $\mathrm{pH}$ of pure water is 7.0. In general, water with a $\mathrm{pH}$ lower than 7 is considered acidic, and with a $\mathrm{pH}$ greater than 7 , basic. The normal range for $\mathrm{pH}$ in surface water systems is 6.5 to 8.5 and for groundwater systems 6 to 8.5 Figure 1 shows the $\mathrm{pH}$ of sewage water being used for irrigation of vegitables fields ranged from 8.5 to 7.0 .

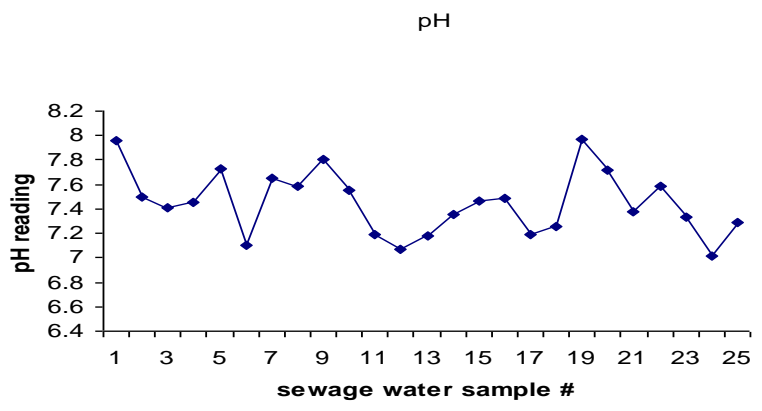

Figure $1 \mathrm{pH}$ of sewage water

\section{EC of Sewage Water}

The value range of typical high quality drinking water lies between $0.005-0.05$ $\mathrm{S} / \mathrm{m}$. Pure water is not a good conductor of electricity. Ordinary distilled water in equilibrium with carbon dioxide of the air has a conductivity of about $10^{-5} \mathrm{~W}^{-1} \mathrm{~m}$ ${ }^{1}(20 \mathrm{dS} / \mathrm{m})$. Because the electrical current is transported by the ions in solution, the conductivity increases as the concentration of ions increases. Thus conductivity increases as water dissolved ionic species. EC of all samples is given in Figure 2 which falls between 3.4 to $0.6 \mu \mathrm{S} / \mathrm{cm}$.

EC of sewage water

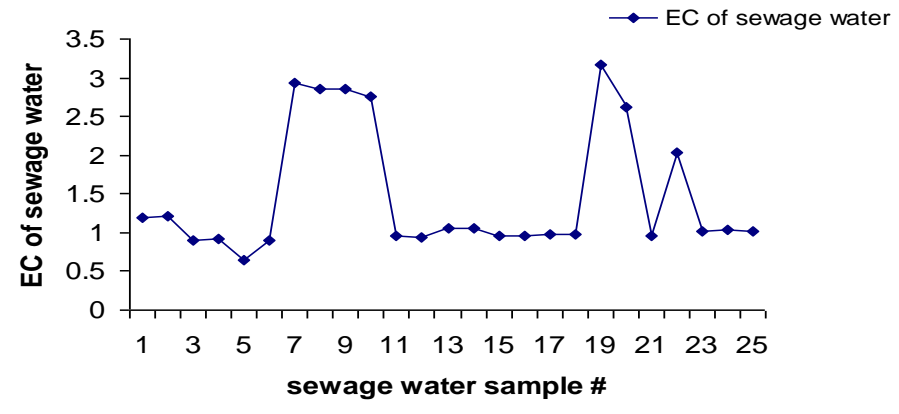

Figure 2 EC of sewage water

\section{Fe in Sewage water and soil samples}

Data in Fig 3 showed that Fe concentration in sewage water was lowest in the sample No. 2, 25 taken from the site Akram Park and Thokar Niaz Baig, Lahore. Highest iron concentrations in the graph were observed in the samples from site no. 21 and 23. These samples were taken from Babu Sabu and Thokar Niaz Baig, Lahore. And, in the remaining samples the concentration of copper was between lowest and highest range of the recorded figure.

Figure 3 also showed concentration of iron in soil samples taken from upper depth of the soil. Sample 15 from the site Sandhan Kalan, Lahore showed lowest concentration of iron. Sample 23 from Thokar Niaz Baig had highest copper concentration followed by sample 5, 8 and 10 taken from Bakar Mandi, Darogha Wala and Sandhan Kalan. 


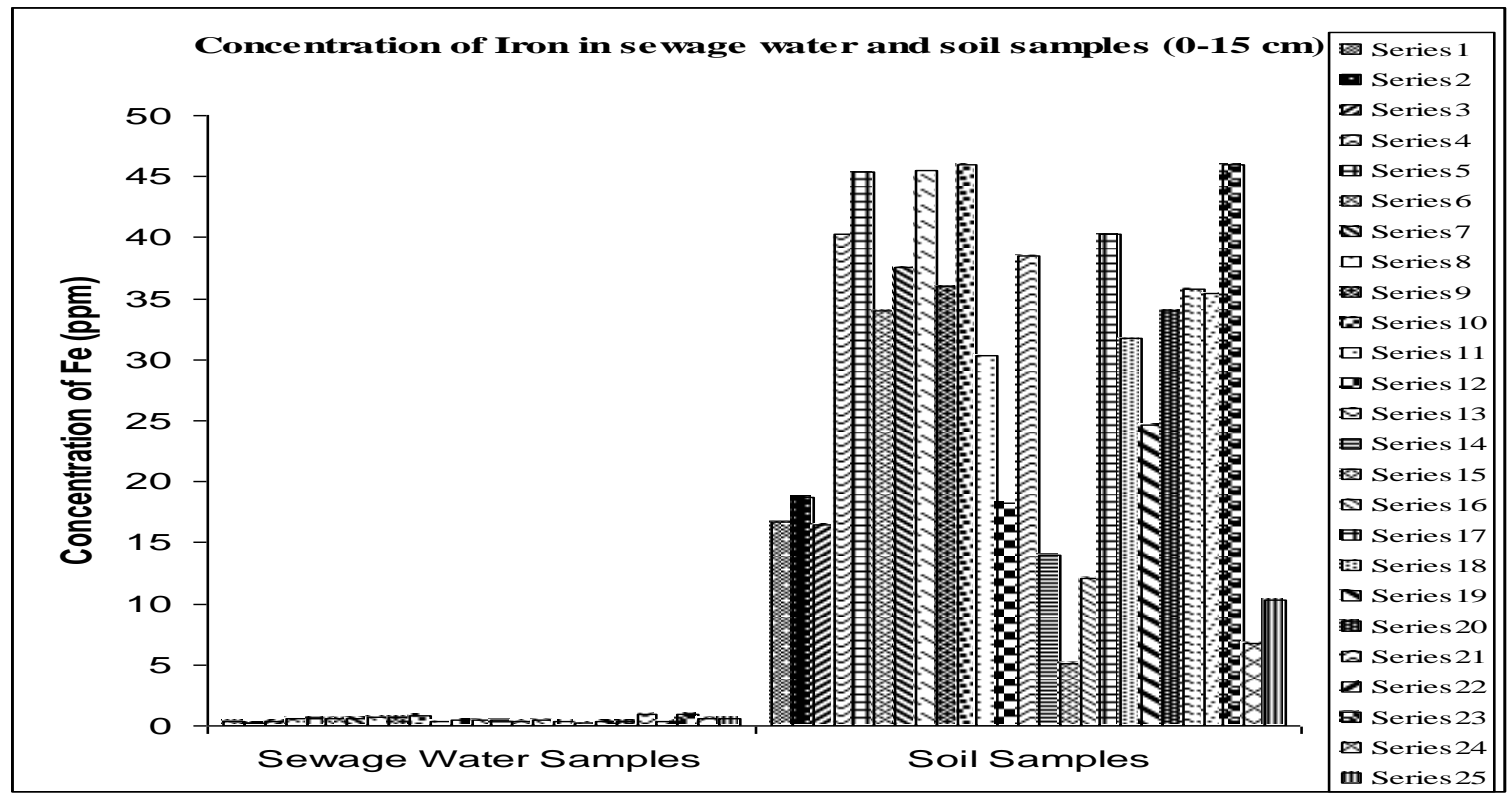

Figure $3 \mathrm{Fe}$ concentration in Sewage water and soil

\section{Mn concentration in Sewage water and soil samples}

Figure 4 presented data regarding zinc concentration in sewage water and soil samples. It is clear from the figure that highest manganese concentration in soil sample taken from the depth of $0-15 \mathrm{~cm}$ was observed in sample no. 5, 7, 13 and

17 which were taken from Bakar Mandi, Darogha Wala, Sandhan Kalan and
Ghosia Colony while lowest manganese concentration was observed in sample 15 and 24 taken from Sandhan Kalan and Babu Sabu Lahore. Data for Sewage water showed that the manganese concentration was lowest in the sample no. 13, 14 and 15 taken from the site Ghosia Colony and Sandhan Kalan. Samples from site no. 19 and 23 showed highest concentration of zinc. These samples were taken from Thokar Niaz Baig, Lahore.

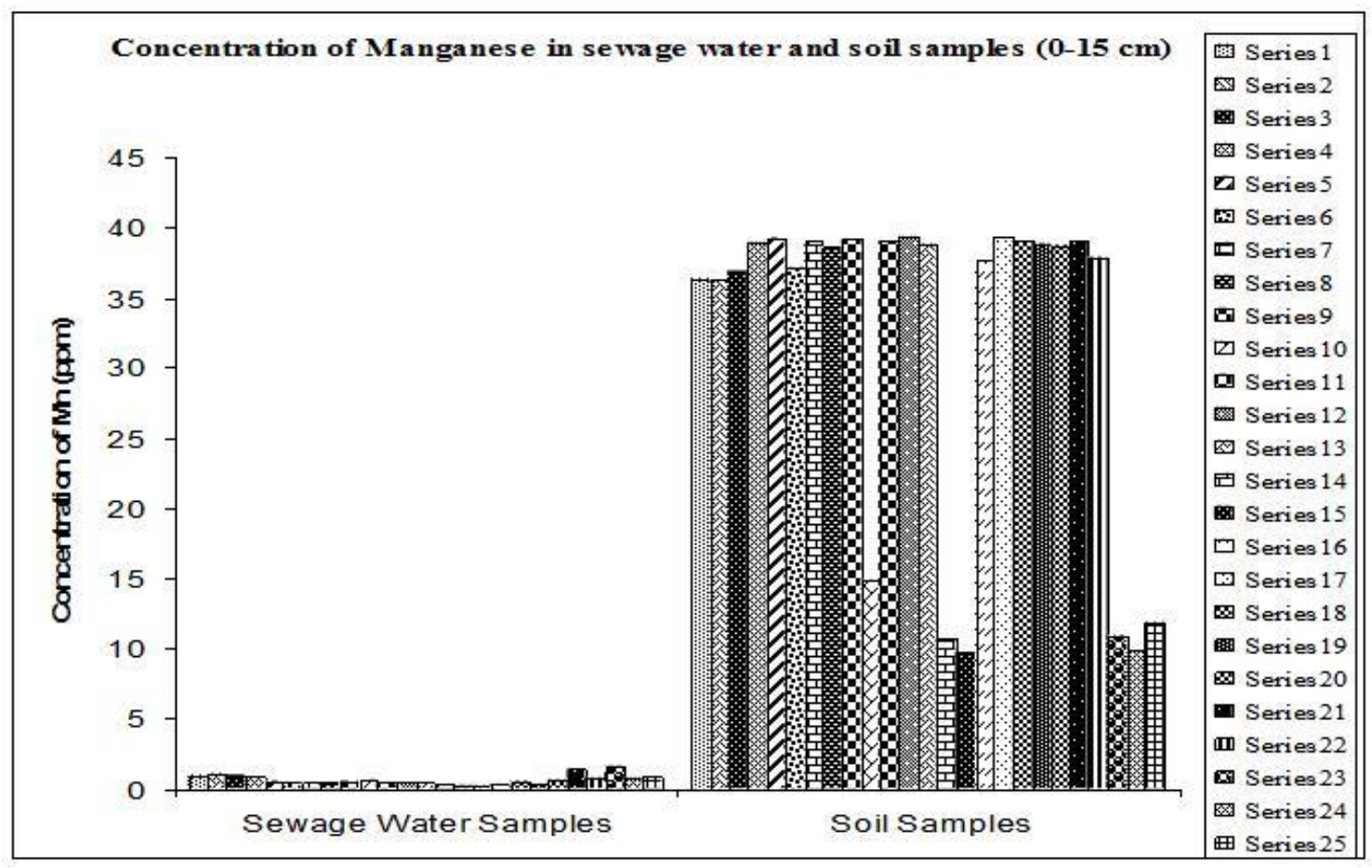

Figure $4 \mathrm{Mn}$ concentration in Sewage water and soil

\section{$\mathrm{Pb}$ concentration in Sewage water and soil samples}

Data about lead concentration in sewage water and soil samples is given in Figure 5. The given data showed that lead concentration in sewage water was lowest in the sample No. 1 followed by sample 2 and 3. These samples were taken from the sites Akram Park and Bakar Mandi. Highest lead concentrations in the graph were observed in the samples from site No. 23 followed by sample number 20. These samples were taken from Babu Sabu and Thokar Niaz Baig, Lahore. And, in the remaining samples the concentration of nickel was between lowest and highest range of the recorded figure.

Figure 5 also showed concentration of lead in soil samples taken from $0-15 \mathrm{~cm}$ depth. Sample 11 and 16 from the site of Akram Park and Ghosia colony had the lowest concentration of lead. Highest contents of lead were recorded in Sample 5 followed by sample No. 8. These samples were taken from Bakar Mandi and Darogha Wala Lahore. 


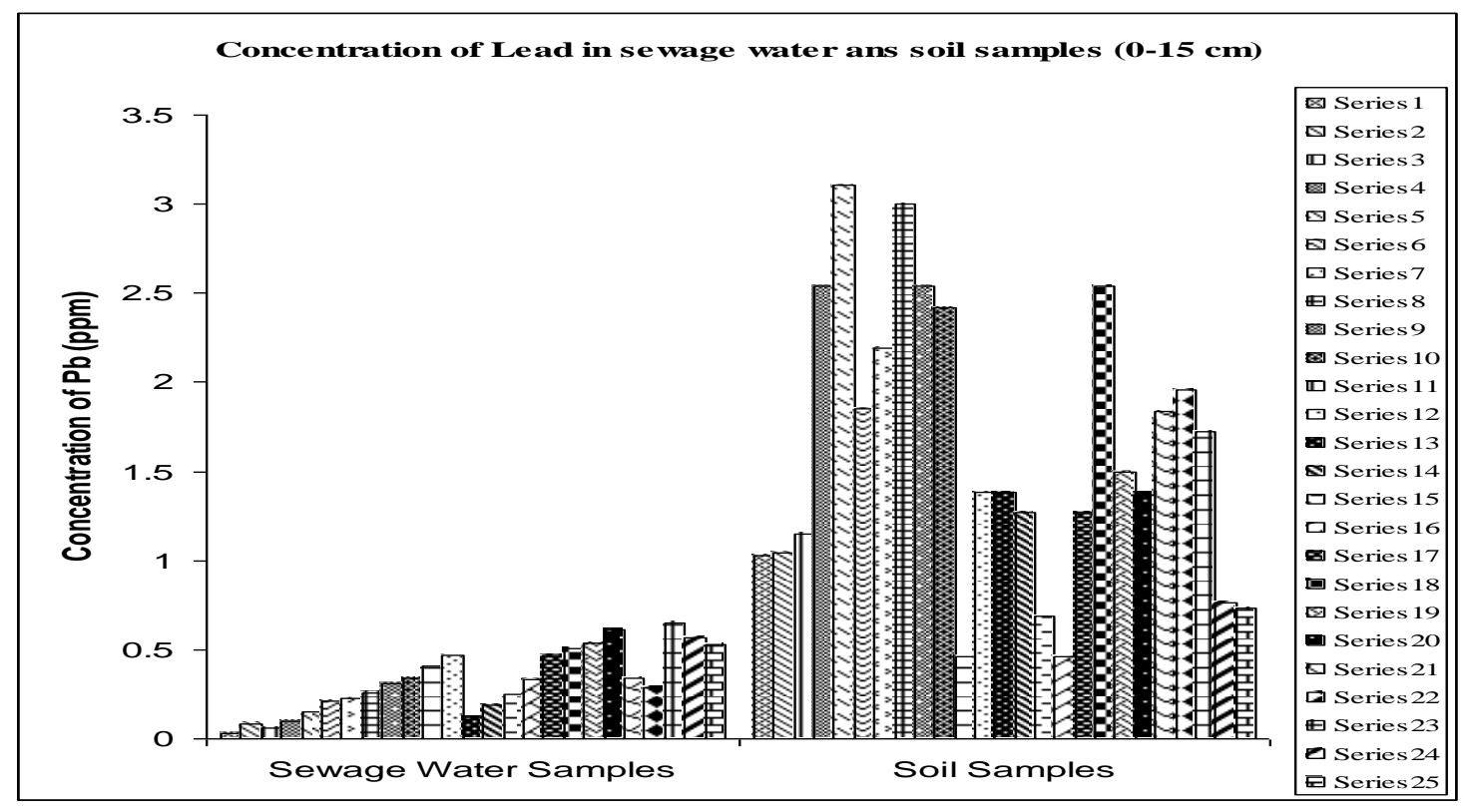

Figure $5 \mathrm{~Pb}$ concentration in Sewage water

\section{Fe in Sewage water and vegetable leave}

Data in Fig.6 showed that iron concentration in sewage water was lowest in the sample No. 11, 12 taken from the site Sandhan Kalan and Akram Park. Similarly, sample No. 2, 14 and 22 taken from Akram Park, Sandhan Kalan and Thoka Niaz Baig respectively almost showed the lowest concentration. Highest iron concentrations in the graph were observed in the samples from site No. 21 and 23. These samples were taken from Babu Sabu and Thokar Niaz Baig, Lahore.
And, in the remaining samples the concentration of copper was between lowest and highest range of the recorded figure.

Figure 6 also showed concentration of iron in vegetable leaf samples. Sample 9, 16, 24 and 25 from the site of Ghosia Colony, Babu Sabu and Thokar Niaz Baig, Lahore showed lowest concentration of iron. Highest iron concentrations were recorded in sample No 13 and 14 taken from Ghosia Colony and Sandhan Kalan, Lahore.

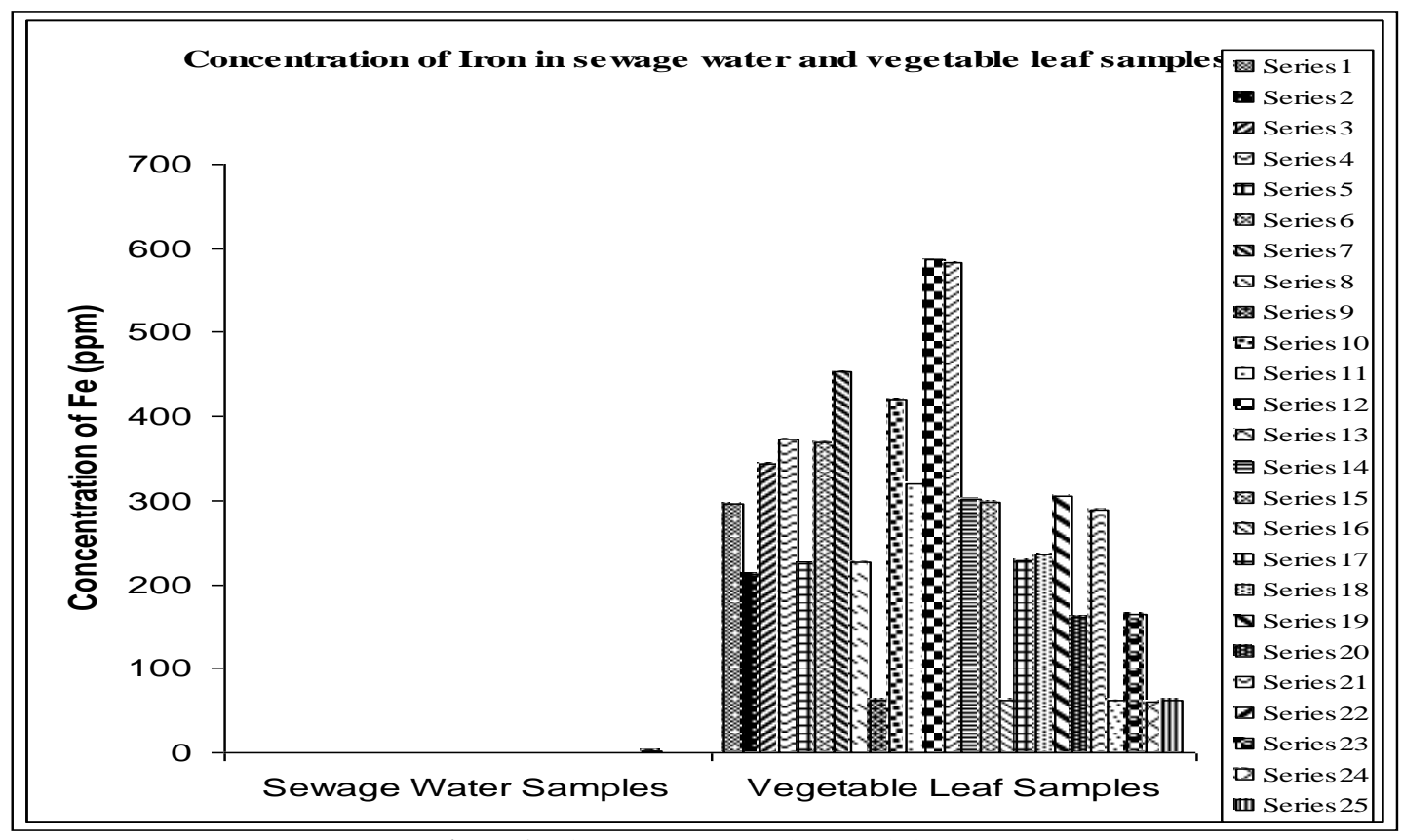

Figure $6 \mathrm{Fe}$ in Sewage water and vegetable leaves

\section{Mn concentration in Sewage water and vegetable leaves}

Figure 7 presented data regarding manganese concentration in sewage water and vegetable leaf samples. It is cleared from the figure that highest manganese concentration in vegetable leaf samples was observed in sample No. 19 which was taken from Thokar Niaz Baig. Data for Sewage water showed that the manganese concentration was lowest in the sample no. 1, 2 and 3 taken from the site Akram Park and Bakar Mandi. Samples from site no. 19 and 23 showed highest concentration of manganese. These samples were taken from Thokar Niaz Baig, Lahore. 


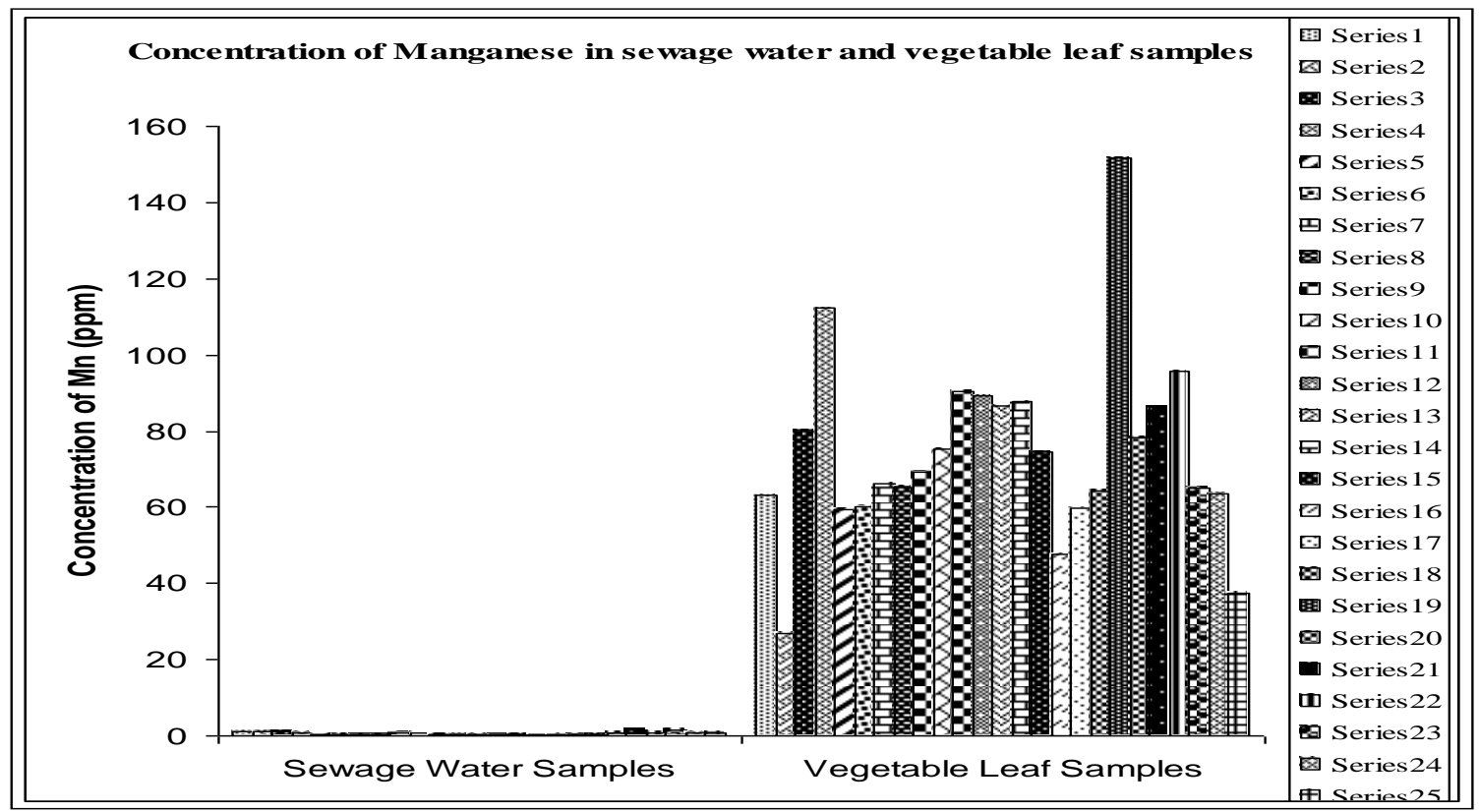

Figure $7 \mathrm{Mn}$ concentration in Sewage water and vegetables leaves

$\mathrm{Pb}$ concentration in Sewage water and vegetable leaves

Data about nickel concentration in sewage water and vegetable leaf samples is given in Figure 8. The given data showed that lead concentration in sewage water was lowest in the sample No. 1, 5 and 13 taken from the sites Akram Park, Bakar Mandi and Ghosia colony. Highest lead concentrations in the graph were observed in the samples from site no. 21 followed by sample number 22 and 25 .
These samples were taken from Babu Sabu and Thokar Niaz Baig, Lahore. And, in the remaining samples the concentration of lead was between lowest and highest range of the recorded figure.

Figure 8 also showed concentration of lead in vegetable leaf samples. Sample 17 from the site of Ghosia Colony had the lowest concentration of lead. Highes contents of lead were recorded in Sample 22 taken from Thokar Niaz Baig, Lahore.

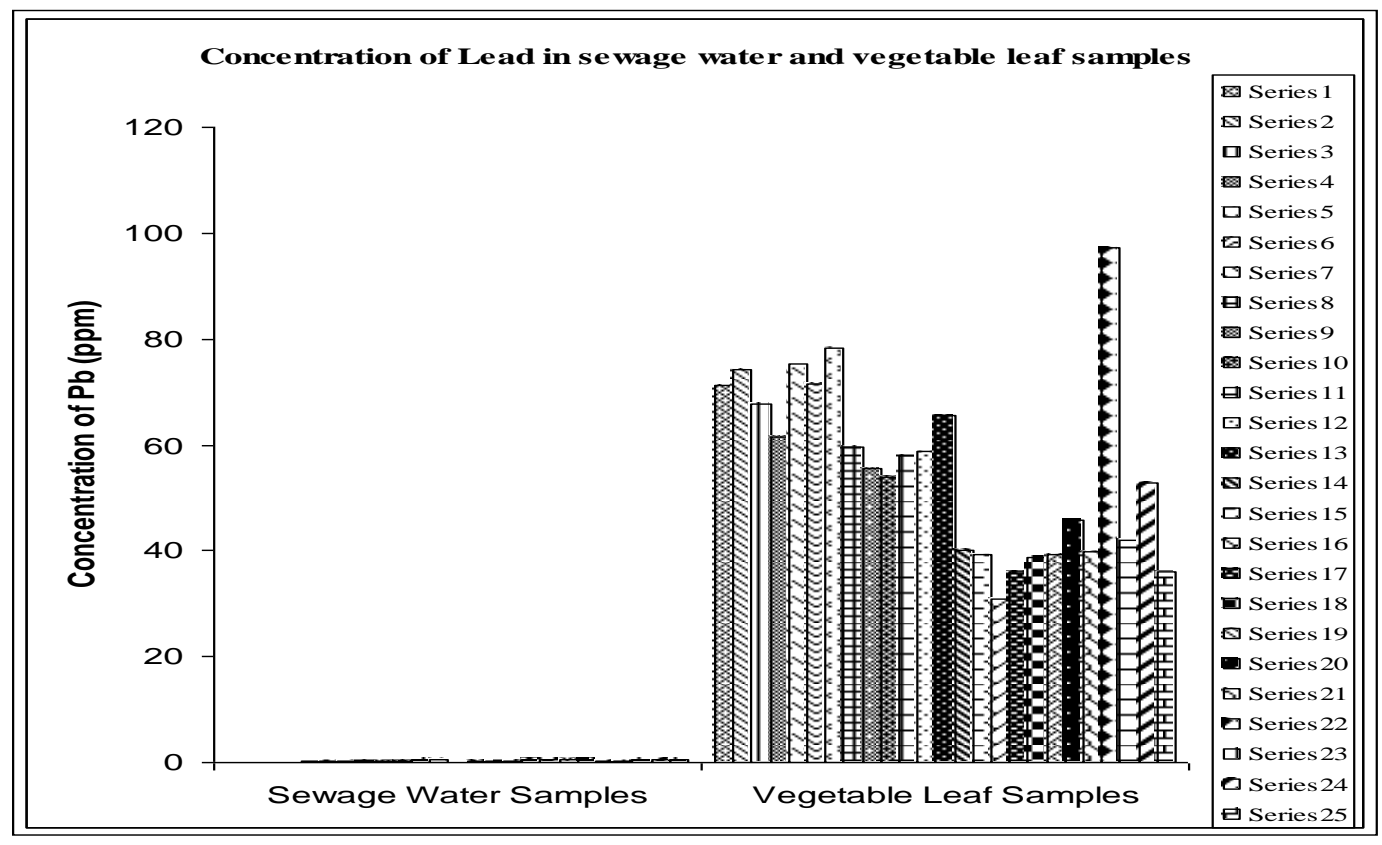

Figure $8 \mathrm{~Pb}$ concentration in Sewage water and vegetable leaves

\section{DISCUSSION}

Study was carried out to detect $\mathrm{Cu}, \mathrm{Pb}, \mathrm{Cd}, \mathrm{Fe}, \mathrm{Mn}, \mathrm{Zn}$ and $\mathrm{Ni}$ concentration in soil and vegetables irrigated with sewage water since last 40 years permanently. Spinach, turnip, brinjal, cabbage, pumpkin, coriander, radish and cauliflower were the main vegetables. In general, the suitability of soils for receiving wastewater without deterioration varies widely, depending on their infiltration capacity, permeability, cation exchange capacities, phosphorus adsorption capacity, texture, structure, and type of clay mineral (Ivan and Earl, 1972, Farid et al., 2013a).

In developing countries, the more attention of public and governmental agencies is towards the contamination of soil by heavy metals (Yanez et al., 2002; Ehsan et al., 2013). Mainly, the human contact to soil contamination is through food chain or by accidentally soil ingestion. In this investigation we mainly focused on these two exposer ways. The metal transformation from soil to plant is key component of human contact to heavy metals through food chain (Sharma et al., 2007). Present investigation and previous finding (Liu et al., 2005; Muchuweti et al., 2006; Sharma et al., 2007) describes that the plantation grown on those soils which are irrigated from wastewater pose a main human health concern. The different vegetables have different metal content which is mainly influenced by the nature and absorption capacity each plant for different metals which changed due to many factors like, plant type, soil type, composition of soil and other environmental interferences (Zureraet al., 1989; Taj et al., 2013).

The results of our study showed agreement with earlier studies describing continuous irrigation with wastewater results in elevated levels of heavy metals in edible parts of food crops (Liu et al., 2005; Khan et al., 2008) Vegetables irrigated with wastewater containing heavy metals did not show any phenotypic abnormalities and no previous findings has been found about 
these effects (Gupta et al., 2010). Plants have different abilities to accumulate metals from soil (Cui et al., 2004; Wang et al., 2006).

\section{pH}

The use of wastewater for irrigation has led to variations in physicochemical characteristics of soil and uptake of heavy metal by food crops, mainly vegetables.

Changes in $\mathrm{pH}$ of soil are mainly depending on $\mathrm{pH}$ of wastewater used for irrigation and $\mathrm{pH}$ of soil has excessive influence on bioavailability and mobility of heavy metals. Our results describes that regular application of wastewater for irrigation led to raised heavy metal level in soil and edible parts of crops. Accumulation of heavy metal in vegetables is gaining more attention due to its potential public health concern (Cui et al., 2005; Bi et al., 2006).

\section{EC}

The bioavailability of heavy metals to plant is also affected by the EC Positive correlation found between the EC values and $\mathrm{Zn}$ contents in the selected plants (Cousinia sp. and C. congestum). Same trend was established among EC values and $\mathrm{Fe}$ contents in lower parts (below the surface) of $\mathrm{C}$. congestum, $\mathrm{V}$. speciosum and any part of C. juncea. In the root of C. juncea and in any part of Cousinia sp. EC had negative effect on Mn uptake (Ehsanet al., 2013). The dissimilarity in number of cases simply involves that, in estimating heavy metal uptake by the plants the isolation is not a dominant factor. In fact, it may be the diversity and interface of every feature, in addition to variety of heavy metals and organic content.

\section{Mn}

The permissible level of $\mathrm{Mn}$ is $0.2 \mathrm{mg} \cdot \mathrm{kg}^{-1} \mathbf{W H O}, \mathbf{1 9 9 5}$ ), and the results of ou study are higher than of this limit. The elements responsible for high portion of $\mathrm{Mn}$ in vegetables were supposed to by the application of fertilizers and agricultural pesticides and of soil type (Sridhara et al., 2008; Tauqeer et al., 2013).

Ni

$\mathrm{Ni}$ is a lethal heavy metal. The safe level of Ni set by WHO (1995) is $0.2 \mathrm{mg} \mathrm{kg}$ ${ }^{1}$.The smaller quantity of $\mathrm{Ni}$ is found in food stuffs of many plants but its higher amount is found in food stuffs like nuts, seeds and grains (National Food Agency of Denmark, 1995). Weigert (1991) investigated that concentration of $\mathrm{Ni}$ nearby $68 \mathrm{mg} \mathrm{kg}^{-1}$ by fresh weight can be harmless for its consumption. $\mathrm{Ni}$ can safely be extracted as organic matter because more than $90 \%$ is taken in held in which reduce the risk to Ni exposure. The previous studies of Otitoloju(2003) and Sharma et al (2008) described that the $\mathrm{Ni}$ level was higher than of permissible limits described in different literatures.

\section{$\mathbf{P b}$}

The maximum level of $\mathrm{Pb}$ in edible parts of crops established by WHO (2001) for human health is $0.3 \mathrm{mg} \cdot \mathrm{kg}^{-1}$. The higher level of $\mathrm{Pb}$ in soil and plants parts is attributed to lead acid batteries as waste dumped in streams and rivers which further used to irrigate the crops. The $\mathrm{Pb}$ uptake can be increased by increasing organic matter and $\mathrm{pH}$ of soil. Lead is a serious body cumulative it enters in body through water and air and cannot be detached from vegetables and fruits by washing (Sharma et al., 2007). According to our results the lead showed a little availability and similar results were also reported by Blaylock et al., (1997) and Salt and Kramer (2000). Pb is very toxic metal and can damage the plants, although large amount of $\mathrm{Pb}$ is usually accumulate without showing visible differences in their yield and appearance. In most of plants the accumulation of $\mathrm{Pb}$ can increase several hundred times than permissible limits for human (Wierzbicka, 1995). Pb introduction in food chain can affect the human health and the accumulation in vegetables has increasing attention (Coutate, 1992).

\section{CONCLUSION}

This study concluded that the excessive use of sewage waste water for the irrigation of vegitables significantly harm the growth, yield and production of vegitables and capacity of soil to different depths. Moreover, the sewage water containing heavy metals also counter affect the groweth of vegitables by acccumulating in different plant tissues. In this view these heavy metals may also introduced in food chain and imbalance the environmental energy flow.

Acknowledgments: We are highly thankful to the Ayyub Agricultural Research Instituion, Faisalabad, Pakistan for their instrumental and technical support in this study.

\section{REFERENCES}

ABBAS, S. T., SARFRAZ, M., MEHDI, S. M., \& HASSAN, G. 2007. Trace elements accumulation in soil and rice plants irrigated with the contaminated water. Soil and Tillage Research, 94, 503-509. http://dx.doi.org/10.1016/j.still.2006.10.004

Agarwal, S.K. 2002. Pollution Management, Heavy metal pollution. A.P.H publishing company New Dehli. 4, 145-163.

CHEN, Y.,WANG, C., WANG, Z. 2005. Residues and source identification of persistent organic pollutants in farmland soils irrigated by effluents from biological treatment plants. Environment international, 31(6), 778-783. http://dx.doi.org/10.1016/j.envint.2005.05.024

DEMBITSKY, V.M., REZANKA, T.2003. Natural occurrence of arseno compounds in plants, lichens, fungi, algal species and microorganisms. Plant Science, 165, 1177-1192.http://dx.doi.org/10.1016/j.plantsci.2003.08.007

EHSAN, S., ALI, S., NOUREEN, S., FARID, M., SHAKOOR, M. B., ASLAM, A., BHARWANA, S. A., TAUQEER, H. M. 2013. Comparative assessment of different heavy metals in urban soil and vegetables irrigated with sewage/industrial waste water. Ecoterra, 35, 37-53

FARID, M., ALI, S., SHAKOOR, M.B., BHARWANA, S.A., RIZVI, H., EHSAN, S., TAUQEER, H.M., IFTIKHAR, U., HANNAN, F. 2013a. EDTA assisted phytoremediation of Cadmium, Lead and Zinc. International Journal of Agronomy and Plant Production, 4 (11), 2833-2846.

FARID, M., SHAKOOR, M. B., EHSAN, S, ALI, S., ZUBAIR, M., HANIF, M. S. 2013. Morphological, physiological and biochemical responses of different plant species to Cd stress. International Journal of Chemical and Biochemical Sciences, 3, 53-60

IVAN, F.S., EARL, E.A. 1972. Soil limitations for disposal of municipal waste waters. Michigan State University Research Report, 195:54.

LIU, W.H., ZHAO, J.Z., OUYANG, Z.Y., SODERLUND, L., LIU, G.H. 2005 . Impacts of sewage irrigation on heavy metals distribution and contamination. Environment International,31,

812.http://dx.doi.org/10.1016/j.envint.2005.05.042

LONE, M.I. (1995). Comparison of blended and cyclic use of water for agriculture. Final Research Report of Project ENGG. (13) 90. UGC. Islamabad.

MALLA, R., TANAKA, Y., MORI, K. TOTAWAT, K.L. 2007. Short term effect of sewage irrigation on chemical buildup in soil and vegetables. International Commission of Agricultural Engineering. International CIGRE journal Manuscript, 9,p14. ISSN: 1682-1130

MITRA, A., GUPTA, S.K. 1999. Effect of sewage water irrigation on essential plant nutrients and pollutant elements status in a vegetable growing area around Calcutta. Journal of Indian Society of Soil Science, 47, 99-105.

SHARMA,R.K., AGRAWAL, M., MARSHALL, F.M. 2007. Heavy metal contamination of soil and vegetables in suburban areas of Varanasi, India. Ecotoxicology and Environmental Safety, 20(2), 188 194.http://dx.doi.org/10.1016/j.ecoenv.2005.11.007

SIDDIQUE, K., ALI, S., FARID, M., SAJID, S., ASLAM, A., AHMAD, R. TAJ, L., NAZIR, M.M. 2014. Different heavy metal concentrations in plants and soil irrigated with industrial / sewage waste water. International Journal of Environmental Monitoring and Analysis, 2(3), 151-157. http://dx.doi.org/10.11648/j.ijema.20140203.14

TAJ, L., HUSSAIN, S., ALI, S., FARID,M., ANWAR-UL-HAQ, M.,UMME-EHABIBA., SAJID,S., SHARIF, N., 2013. Physico-Chemical analysis of ground water contamination caused by Industrial waste water In Faisalabad, Pakistan.International Journal of Plant, Animal and Environmental Sciences, 3(4), 140-146

TARAR, R.N. 1997. Pakistan's surface water scenario in $21^{\text {st }}$ century and needed actions, In: Proceedings of International Symposium. "Water for $21^{\text {st }}$ century, demand, supply, development and socioeconomic issues". Centre of Excellence in Water Resources Engineering, University of Engineering and Technology, Lahore, Pakistan.

TAUQEER, H.M., ALI,S., FARID, M., SHAKOOR, M.B., HANNAN,F. AHMAD, R., IFTIKHAR, U. 2014. Physico-Chemical Characterization of Wastewater Discharged from Different Textile Industries and Their Ranking on the Basis of Wastewater Treatment Facilities and Hygienic Conditions. Journal of Applied Science and Environmental Sanitation, 9(2), 123-128

YANEZ, L., ORTIZ, D., CALDERON, J., BATRES, L., CARRIZALES, L. MEJIA, J. 2002. Overview of human health and chemical mixtures: problems facing developing countries. Environmental Health Perspective, 110(6), 901-909. ZHEN-GUO, S., XIAN-DONG, L., CHUN-CHUN, W., HUAI-MAN, C.H., HONG, C.H. 2002. Lead Phytoextraction from contaminated soil with high biomass plant species. Journal of Environmental Quality, 31, 1893 1900.http://dx.doi.org/10.2134/jeq2002.1893 